\title{
Regional science in a physical/virtual more/less world
}

\author{
David A. Plane ${ }^{1}$
}

Received: 3 April 2016 / Accepted: 21 July 2016 / Published online: 8 August 2016

(C) Springer-Verlag Berlin Heidelberg 2016

\begin{abstract}
In this paper, originally presented as my Presidential Address at the 55th WRSA Annual Meeting, I discuss how demographic trends currently underway will need a regional science that responds to the needs of a more/less rather than a more/more world. I ponder the concepts of daily activity and awareness spaces and the ways in which some of the most important questions in regional science have been fundamentally altered by the Internet, cell phones, social media, and other new forms of communications and ways to conduct transactions. I speculate about the nature of distance and other locational concepts in the cyberspace, and I contend that as people live in both physical and virtual activity spaces, the local realm has actually assumed newly increased importance.
\end{abstract}

Keywords Activity and awareness space · The Internet · Distance

Paper presented at the 55th Annual Meeting of the Western Regional Science Association February 16, 2016-Kona, Hawaii.

$凶$ David A. Plane

plane@email.arizona.edu

1 School of Geography and Development, University of Arizona, ENR2 Building, Room 429, 1064 E. Lowell Street, Tucson, AZ 85721, USA 


\section{Introduction}

There has been a constant extension of the range of mobility. ... Popular conceptions of speed and distance have been completely revised.... The tempo of life is speeded. ... An interconnecting, interconnected web of communication has been woven about the individual. ... The web has developed largely without plan or aim. The integration has been in consequence of competitive forces, not social desirability.

Recent Social Trends in the United States, Report of the President's Research Committee, 1933 (as quoted in Meinig 2004, p. 1).

It is a great honor for me serve in the role of Western Regional Science Association President. I had the singular pleasure of being the organizer for some 20 previous WRSA Annual Meetings. Each year, when I would talk to our incoming President about giving the traditional luncheon address, I always suggested two things: (1) have fun with it; and (2) keep it short. Over the years, we have, in fact, had quite a few very thoughtful - and fun-addresses. I learned, however, that asking an academic to be brief is a fool's mission. Nevertheless, I promised Rachel Franklin, our current Executive Director, I would make mine short... more or less.

Which brings me to the title of this address: "Regional science in a physical/virtual more/less world." What do I mean by a physical/virtual more/less world? I came up with that phrase after thinking about what basic concepts in regional science have most motivated my research career. I decided there are two or three that especially stand out. And then I started pondering how those concepts have been fundamentally altered by changing characteristics of the world during my life span. And then I selected a pair of quotes to start this sharing of thoughts on a suitably lofty plain.

In the holy book of Hinduism, the Bhagavad Gita, it is said: "Suppose a thousand suns should rise together in the sky. Such is the power of the shape of the infinite." Keeping that glorious image in mind, ponder next some more down to earth words. These are those of Tony Smith, my Penn Dissertation advisor. He spoke them in Philadelphia in 2003 at a special session of the 50th anniversary North American Meetings organized by Andy Isserman in the format of a Quaker meeting. Each of us was invited to stand up and talk about what had been learned in the first half-century of regional science. When Tony's turn came, he said something like: "Sometimes I think the only two things we've learned in regional science are: (a) people generally prefer to make shorter than longer trips, and (b) they would rather have more space than less space."

The green flash that came to me while looking to link the cosmic aphorism of the Bhagavad Gita together with Tony's pithy insights was this: The Internet, or, more broadly, the whole electronic web of communications on which we now spend much of our lives, is the latest, greatest innovation reshaping human geographies. And it is that new electronic universe that is quietly and radically undermining those pair of things that we just might, maybe, have learned, thus far, in regional science.

We now live with our feet in the physical world, but with half our brains and attention off in the virtual one. The implications of the virtual world on how business 
gets transacted, how we engage with one another, and how we access and accumulate knowledge all have rather profound implications for the locational or "where" questions that regional scientists research, as well as for the policy questions that our analytical methods need to be designed to help answer.

Whereas our multidisciplinary field was founded to study the spaces of a material world, one where location and physical distance matter, increasingly it is a different kind of space - what I shall call affinity space - that characterizes the more ethereal realm of the worldwide web. I am going to argue that we have defined progress, in our physically defined world, on the basis of "more is more." But at this juncture of human history, when we've embarked on a voyage of discovery in the boundless, ever-expanding web world, I believe the key to progress will be coming to grips with how to interact within a "more and/or less" world. And that is going to involve taking more seriously that dictum of modern architecture coined by Mies van der Rohe that "less is more." And I actually think the more time we spend in virtual affinity space, and the less time, consequently, we devote to moving about in physical space, the more that distance matters!

My longest enduring love affair in regional science has been with the gravity model. In its basic, social physics, unconstrained form, the human geography gravity model can be written as:

$$
M_{i j}=k \frac{P_{i} P_{j}}{D_{i j}^{b}}
$$

Its three essential components, movement or spatial interaction, population, and distance, have been my primary fascinations. These are surely among the most primitive and foundational concepts of regional science (perhaps along with a few others, such as regions, economies, firms, households, factors of production, and amenities). So what I want to focus on in this address are evolving population trends and the changing nature of distance and spatial interaction. In both instances, I will suggest we need to shift from thinking about a more/more world to a more/less world. In the process of explaining that, I shall also share some ideas for the kinds of regional science needed in our brave new virtual/physical more/less world.

\section{Over the hill of the demographic transition}

Regional science was born and came of age during a quite short but immensely important time span of human history: the period when populations around the world were exploding. The inflexion point of what looks to be the logistic time curve of global population was reached in the 1960s, when the world's growth rate had zoomed to $2 \%$ per year. The global rate has now been cut to about half its peak level. Now, however, the base population to which that rate applies is double what it was back in the 1960s when John Lennon was asking us to imagine all the people. Even though fertility rates, worldwide, have now dropped to almost long-term replacement level, in the near-term future we will need to find imaginative ways to deal with an additional two billion or so people who are still to be added to global population. This remaining increase will 
result, almost entirely, from age momentum in a shrinking number of countries where large population proportions have yet to pass through their child-bearing years.

Regional science's general systems approach and its analytical methods and theories were well suited to the expansionary times following World War II in the countries of North America, Western and Northern Europe, Japan, Korea, and Australasia. In the most developed countries, the process of bringing down mortality had been underway ever since the mid-seventeenth century period of the Enlightenment, with significant scientific advances being made in medicine, sanitation, and food security. Fertility, however, had remained relatively high. The massive postwar baby boom was well underway when the first regional science conference was held in Detroit in 1954. By the late 1950s, the US total fertility rate would stand at 3.7: For every fertile age woman, Americans, on average, were bringing almost four children into the world. At the start of that first decade after World War II, only about one-third (34\%) of American women 25-34 years of age were in the wage labor force. Two decades later, in the $1970 \mathrm{~s}$, the US total fertility rate had dropped to $<2.00$, and it has remained at or slightly below the long-term replacement level of 2.1 ever since. In contrast to the situation during the formative period for regional science, by 2000 more than three-quarters (76.3) of American women 25-34 were in the labor force.

By the 1970s, enormously heightened material prosperity had been achieved for the majority of citizens in rich countries, such as the USA. Population growth and economic expansion had gone hand in hand, but, with widespread affluence, some began to question whether ever more consumption should continue to be a first and foremost societal goal. The recent Great Recession in the USA, which started in December of 2007 and led to a subsequent worldwide recession in 2009, has focused current attention on the sustainability of high middle-class standards of living and equitable income distributions. Slow or negative population growth and aging populations with declining percentages in the traditional prime working years are going to be the trends throughout the developed countries in the decades ahead.

Whereas it took centuries for fertility to drop to replacement levels or below in the developed countries, across almost all of the developing world, fertility transitions are now being completed in record short time spans. As desired family size has rapidly dropped, country after country has experienced, or soon will be experiencing, a generation or two of the "demographic dividend." The demographic dividend is that "sweet spot" in age composition when a country's prospects for rapid economic development are facilitated while youth dependency is radically lowering, elderly dependency is remaining low, and the bulk of the population is passing through their most productive labor force years.

But aging is inevitable. Soon, the "demographic divide" between more and less developed countries will pass into history. All around the world, businesses and governments will have to adapt to slow, no, or negative population growth being the norm, and to no-longer youthful age structures. Franklin and Plane (2016, forthcoming) is an attempt to assess what new kinds of regional science will be needed as the world passes "over the hill" of the demographic transition.

I believe demography is a powerful driver of economic and societal trends. And aging is one of the few things we can count on, with substantial certainty, in forecasting the future. From a population perspective, regional science is going to need to shift 
from a world where, in most places, ever more and more has been the norm. The underlying demographic dynamic for many regions in the future will be less population with an aging composition. The global issues of the future will not be so much about accommodating and feeding ever more and more new inhabitants, but about resource and energy use and environmental issues, areas which have not, historically, been counted among regional science's core research areas or strengths.

In terms of consumption and resource use, I believe the so-called $I=P A T$ equation is an important and illuminative conceptual framework. Intensity of resource use $(I)$ is posited to be a function of population $(P)$, affluence $(A)$, and technology $(T)$. Whereas population growth is slowing in most countries, for the world as a whole, there are still several generations of people who will be born and who will die before the globe might have less rather than more people. For the majority of the world's population in developing countries, however, slower population growth, smaller families, and more women in the wage labor force are resulting in increasing affluence in ever more and more parts of our planet. So, ceteris paribus, population, and affluence, taken together, seem to inexorably point to more resource use and more environmental pressures. But will that actually be the case?

Humans seem to instinctually assume that whatever trend is underway at the current time is likely to continue and, in fact, to accelerate. And often this leads us to assume the worst. But many human systems include feedback mechanisms. At the outset of regional science, the Club of Rome was making dire Malthusian forecasts of mass starvation. So let's not forget T. Technological change is hard to forecast, but recent experience in computers and electronics illustrates just how rapid and exponentially accelerating scientific progress can be. I am optimistic that human ingenuity may well prove decisive in overcoming the challenges of climate change, the resource ravages of over-consumption, and global environmental catastrophe.

I will turn now to the concept of distance, and how the virtual world —or what I will refer to as the web world - is altering daily lives, human geography, and the need for new kinds of regional science research.

\section{Physical versus virtual space}

\subsection{Time-space convergence and the substitution of virtual for physical transactions}

The diagram in Fig. 1 comes from a paper by Janelle (1968) illustrating what he termed time-space convergence. Shown are the travel times by the fastest available mode between New York and Boston at different historical periods. The slope of the line shows the rate per year by which total travel time was being reduced. New York and Boston were coming closer together most rapidly when railroads were developed because trains could travel substantially faster than stagecoaches. Later on, the automobile resulted in a more modest reduction in travel time because cars do not move all that much faster than trains.

Janelle goes on to point out that, defined in this fashion, time-space convergence is relatively more rapid the farther apart are origins and destinations (see Fig. 2). 


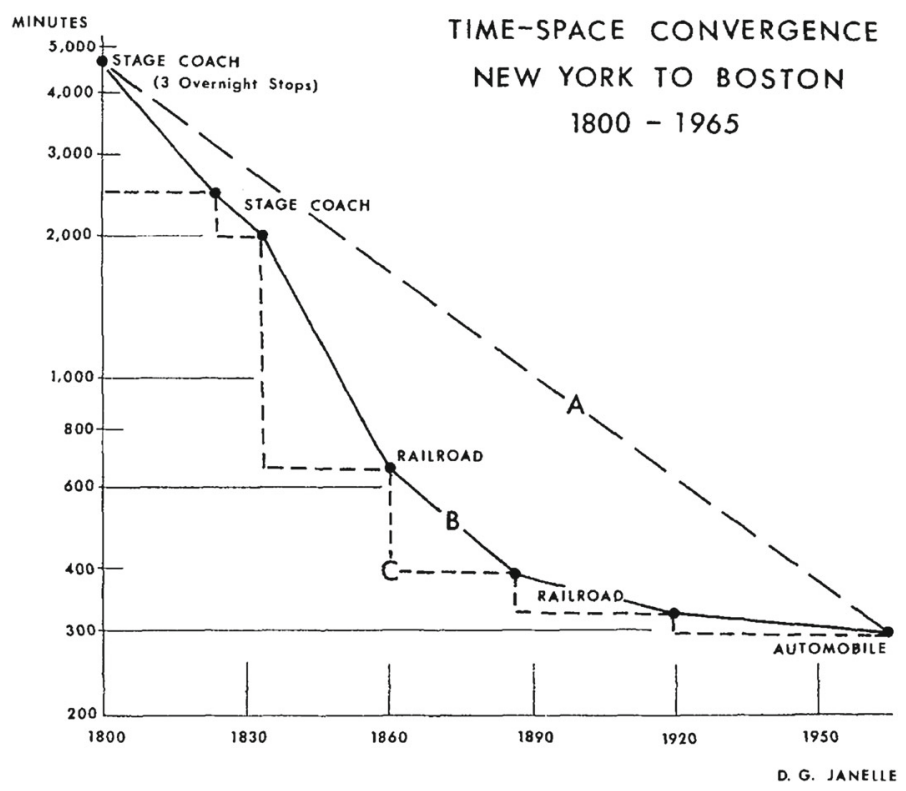

Fig. 1 An illustration of time-space convergence (Source Janelle 1968, p. 7)

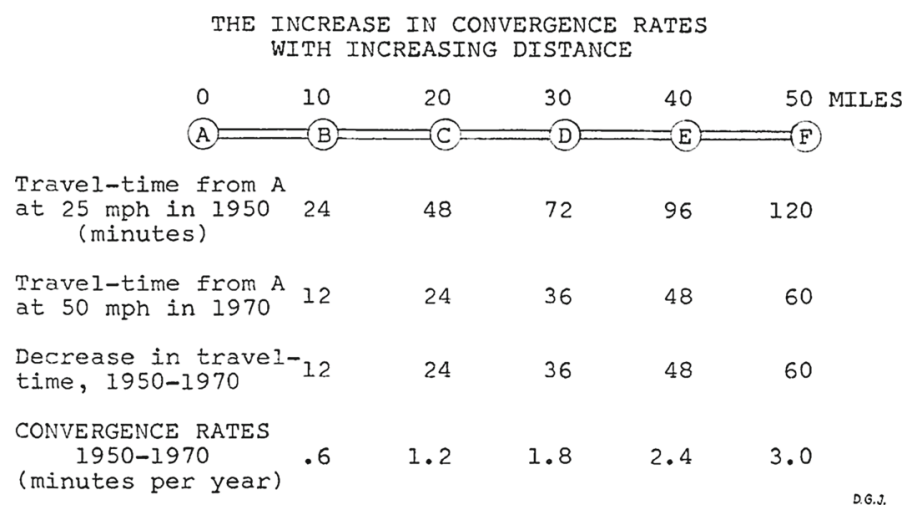

Fig. 2 Example showing how the rate of time-space convergence is greater for more distant than for nearby places (Source: Janelle 1968, p. 9)

If we consider the feasibility of making trips to be a function of the thresholds of time spent en route, then time-space convergence has substantial implications for the central place functions of settlements. Small, nearby hamlets lose some of their functions because larger, more distant centers can be reached more expediently. The increasing concentration of central place functions in the highest order centers means firms can reap greater economies of scale and households can enjoy a broader array of closely proximate goods and services. Over the course of history, and around the globe, transportation advances as well as the much reduced labor requirements of 


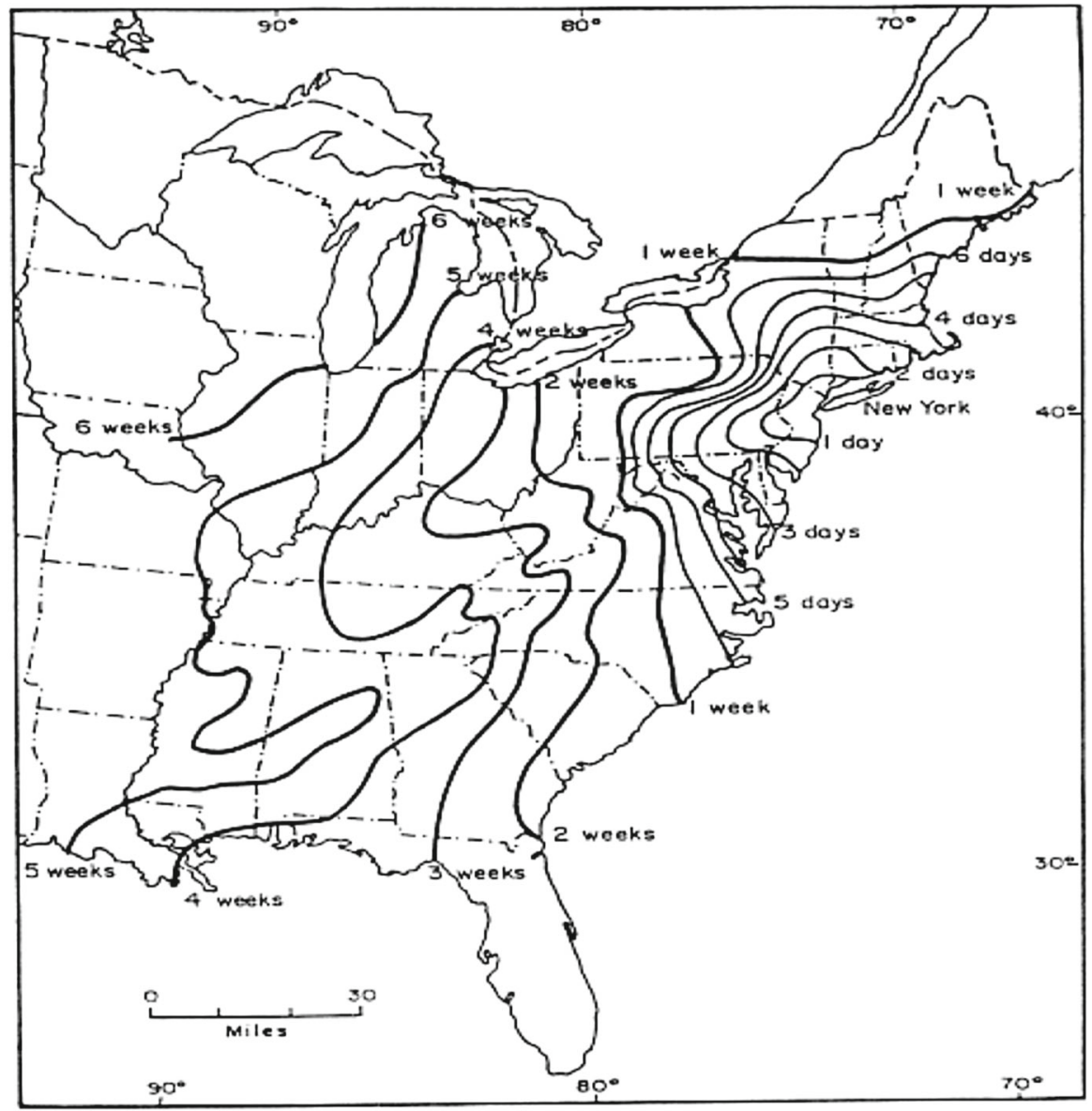

Fig. 3 Rates of travel from New York City in 1800 (Source: Pred 1973)

primary sector industries have resulted in megacities becoming ever more dominant features on the economic landscape.

But even with jet planes and bullet trains, for physical movement, the world of today is not qualitatively different from the one that historical-geographer Allan Pred mapped in Fig. 3. Teleportation is not yet an option. It still takes at least a modicum of time to physically traverse space, and it generally still takes more time to travel longer than shorter distances. Although much reduced in magnitude, the so-called tyranny of distance - also known as the attenuating effect of distance or the friction of distance - continues to significantly affect human affairs. But what really has been changing in unprecedented ways is when physical travel is required.

Pred's maps were drawn to illustrate the flows of information. How long did it take in 1800, say, for news of election results to reach different parts of the USA? Throughout most of human history, communications were dependent on physical transport. The pony express in the US Wild West days could carry the mail faster than 
could marathon runners in ancient Greece, but there was still a substantial time lag in getting out the word to somebody else. But a series of technological breakthroughs, starting with the telegraph and the telephone, followed by the fax, the Internet, and satellite communications, have now rendered communication lags virtually obsolete.

Physical movement and virtual interaction are becoming ever more substitutable. Within the time span of a single generation, at an almost mind-boggling pace ever more aspects of commercial and social relations that once were done in tangible, physical ways are being conducted ethereally, in the virtual realm. Institutions and geographical structures set up to handle transactions carried out in the flesh are undergoing fundamental transformations as larger and larger portions of human affairs are coming to be conducted electronically.

In his recent book about the Internet, after citing an estimate that more than 2.25 billion people were using the Internet as of the end of 2011, Barney Warf contends:

Indeed, for rapidly rising numbers of people around the world, the "real" and the virtual have become thoroughly interpenetrated. In this light, access to cyberspace is no longer a luxury, but a necessity. As its applications have multiplied, the internet is having enormous impacts across the globe, including interpersonal interactions and everyday life, identity formation, retail trade and commerce, governance, and is affecting the structure and form of cities, in the process generating round upon round of non-Euclidean geometries in the context of a massive global wave of time-space compression.

By now, digital reality and everyday life for hundreds of millions of people have become so thoroughly fused that it is difficult, if not impossible, to disentangle them. In this context, simple dichotomies such as "off-line" and "on-line" fail to do justice to the diversity of ways in which the "real" and virtual worlds for hundreds of millions are interpenetrated. (Warf 2013, p. 1)

The transformations wrought by the increasing interpenetration of the physical and virtual worlds have significant implications for those of us who study locational questions. Radical shifts in how basic transactional processes take place are restructuring economic and social landscapes. For a large array of goods and services, brick and mortar stores are disappearing as eCommerce takes bigger bites into market share. Where once consumers making individual shopping trips transported their own purchases home, now more and more tangible goods get shipped and delivered by the agents of retailers. Even more radically, things that formerly had to be physically transported are giving way to downloadable substitutes: paperback books segue into eBooks, record albums and CDs into audio files for iPods and streaming audio, videotapes into streaming video. As channels of wholesaling versus retailing shift, so, too, do the networks of relevance for regional science models of spatial pricing and optimal location.

It is not only major industries that are being radically transformed by new modes of communication and virtual goods and service provision: People's daily lives are also being fundamentally altered. Unlike, e.g., the period in the mid-1800s when freight that had been hauled in slow canal boats was shifting to more rapid rail movement, or the mid-twentieth century when automobiles rapidly replaced streetcars for intra- 
urban commuting, the change to interactions in virtual space represents a qualitative and not just a quantitative shift. Whereas the earliest innovations in communications, the telegraph and the telephone, seemed to have impacts similar to the transportation advances that formed the basis for the concept of time-space convergence, the latest wave of new, participatory technologies and social media are having impacts quite different and in some cases opposite to those of earlier-developed forms of mass media.

Many of the changes we are currently witnessing are not playing out in the geographical directions we might first expect, that is, toward encouraging ever greater and greater homogeneity and globalization. Musicians, who once devoted themselves principally to producing albums and CDs in recording studios, have had to get back on the road again, earning their keep by performing before live concert audiences. Where major publishing houses once kept tight rein on the entry of new authors to book markets, anyone can now self-publish eBooks. There has also been a return to former modes of food production and purchasing, with farmer's markets springing up all across our urban landscapes to sell organic, heritage and heirloom crops to "foodies" participating in a "slow foods" movement. The once dominant national brands of beer are facing stiff competition from hometown micro-brews. The channels of advertising, which were always the bailiwick of big businesses with large budgets for media buys, have been opened up by the virtually free, democratic world of cyberspace, where now anybody can put up their own Web site to peddle their wares. Even the travel industry has been transformed. Whereas once upon a time long journeys might have been required to obtain knowledge about distant localities, in the Internet age we can be virtually anywhere with a few keystrokes or a whispered wish. We can even take a look-see via a webcam.

Leamer and Storper (2001) took on the question of how the Internet affects location in terms of deagglomerative versus agglomerative tendencies. They argue that, like with many previous technological advantages, it makes possible further dispersion of some routine activities, but, on balance, the impacts may favor localization:

Increasingly the economy is dependent on the transmission of complex uncodifiable messages, which require understanding and trust that have historically come from face-to-face contact. This is not likely to be affected by the internet, which allows long distance 'conversations' but not 'handshakes.' (Leamer and Storper 2001, p. 1).

\subsection{Time geography in a virtual/physical more/less world}

The substitution of virtual for physical transactions is wreaking profound changes on how we organize the where and when of our lives. How people lead their daily lives in the physical realm was the basis for a seminal concept of regional science: the set of related notions that came to be called time geography. At the 9th European Congress of the Regional Science Association, Torsten Hägerstrand delivered his presidential address titled "What about People in Regional Science?" There he sketched out the concept of an activity space (Fig. 4). People are assumed to bundle 


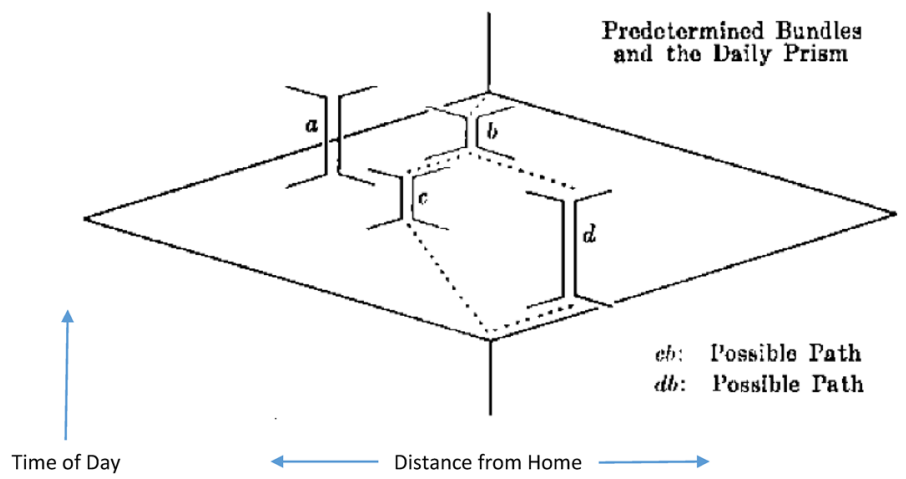

Fig. 4 Bundling of feasible daily activities in an individual's time-space prism (Source: Hägerstrand 1970, p. 16)

together activities that take place at different physical locations and at different times throughout the day. The spaces where an individual's routine daily activity occurs are anchored first and foremost by the home location, and then by an axis representing the journey to workplace or school location. Various capability and authority constraints limit the feasible set of activity nodes, and coupling constraints factor in the time required to travel between the end of one activity to the location the next.

People also, of course, interact with locations other than those where they physically spend time. Through the decades, various concepts of life spaces, action spaces, and awareness spaces have been proposed to map the broader areas about which people have knowledge. Wolpert, in discussing how to model migration decision making, defined a notion of an action space, noting:

Though the individual theoretically has access to a very broad environmental range of local, regional, national, and international information coverage, typically only some rather limited portion of the environment is relevant and applicable for his decision behavior. This immediate subjective environment or action space is the set of place utilities which the individual perceives and to which he responds. This notion of the action space is similar to Lewin's concept of life space - the universe of space and time in which the person conceives that he can or might move about. (Wolpert 1965, p. 163, referring to Lewin 1951)

Similarly, Horton and Reynolds (1971), in exploring the effects of urban spatial structure on individual's daily activities, posited:

Action space is the collection of all urban locations about which the individual has information and the subjective utility or preference he associates with these locations. The subjective utility or preference is evaluated with regard to both potential and actual spatial behavior. Geometrically, action space is characterized by two components: first, its spatial extent as defined by the set of locations; and, second, a generalized surface (discrete and continuous) specifying the utility or preference level associated with each location. An individual's activity space is 
defined as the subset of all urban locations with which the individual has direct contact as the result of day-to-day activities. (Horton and Reynolds 1971, p. 37)

At about the same time, in a consideration of factors affecting intra-urban residential mobility, Brown and Moore (1970) wrote:

...we have adopted the term awareness space to refer to those locations within the total urban space about which the intended migrant household has knowledge (or knowledge above some threshold level) before search begins. Prior knowledge of the characteristics of the urban area derives from two basic sources: the household's day-to-day activities which yield information from direct contact, and information derived at second hand from such channels as acquaintances' experiences and mass media. The set of locations associated with the first source defines the household's activity space, and the set of locations associated with the second source defines the household's indirect contact space. (Brown and Moore 1970, pp. 7-8)

About the shapers of indirect contact space, Brown and Moore said:

...the effect of the mass media upon the form of the indirect contact space is closely related to the spatial characteristics of the individual media.... Similarly, the unique effect of information acquired through acquaintances will be closely related to the spatial characteristics of their activity spaces. Thus, a basis exists for hypothesizing that indirect contact spaces also exhibit strong distance-decay characteristics and are a second-order extension of the searcher's activity space.

(Brown and Moore 1970, p. 8)

Brown and Moore correctly observed that what they called indirect contact space is closely related to the spatial characteristics of the medium of communication. But they could not have foreseen the lurking impacts of the worldwide web. It was in 1961 that the web's Johnny Appleseed, JCR (Joseph Carl Robnett) Licklider, first wrote a memo about what he would come to call the "Intergalactic Computer Network" (Leiner et al. 2016). But even in the late 1970s, when I was a grad student at Penn, the ARPANET was largely seen as a rather curious project of the US Defense Department: The bulk of the users seemed to be a few of us nerds in remote locations interested in playing the computer game ZORK on the MIT computer.

In the early-1970s, mass media were largely locally based: metropolitan daily newspapers, local radio stations, and television channels. Long-distance telephone calls were charged at pricey, federally regulated rates, which were set as a function of distance (as were airline trips and trucking hauls). So yes, awareness of what was going on in other parts of the world was still some kind of function of distance.

Now, scarcely a generation later, the Internet, together with unlimited minutes and data cell phone calling plans, have effectively decoupled activity space and indirect contact space. Today, distance decay may not characterize individuals' indirect contact spaces. Furthermore, the worldwide web has become an essentially parallel universe; it offers spaces that many of us inhabit, together with the physical one, for substantial chunks of our waking hours. 


\subsection{Time use in our new physical/virtual world}

What can traditional measures of how people structure their days tell us about timespace allocation now that a goodly portion of life takes place in the virtual world? The standard methodology for collecting such information is to ask a sample of people to record activities engaged in over the course of the day in time use diaries. This methodology proves far from ideal, however, for tallying up the time people now spend on activities in physical and virtual spaces because time spent in the two realms is so intricately interwoven, with people's attention flitting back and forth between the two realms as they constantly check their cell phones for text messages or emails, google for snatches of information, send tweets and post on social media. It would take a good portion of the day for a respondent to faithfully record each of perhaps many thousand such transactions carried out on a daily basis in a time use diary.

Despite the possibilities of the virtual realm to untie workers from traveling to employer determined workplaces to carry out their tasks, data from the American Time Use survey (U.S. Bureau of Labor Statistics 2016) suggest there have been only marginal increases in work being undertaken from home locations. In 2003, an estimated $19 \%$ of all employees were doing some or all of their work from home. By 2015 , the percentage had increased, but only to $24 \%$. Slightly more than threequarters of workers still do all their work at the job location. The average total time that respondents who did work at home said they spent on such work also went up only marginally over this time period, from 2.6 to $3.2 \mathrm{~h}$ per day. One interesting statistic from the American Time Use survey, however, is the large educational divide in the prevalence of telecommuting and other non-traditional arrangements for working from home. Among those with less than a high school education, only $3 \%$ in 2015 reported doing some or all of their work at home, whereas fully $39 \%$ of respondents with an undergraduate degree or higher were doing some or all of their work at home.

During this same time period, there was a very significant diffusion of Internet usage across most all segments of American society. If not for work, then for dayto-day activities and for social purposes, Americans are now overwhelmingly web users. According to statistics tracked by the Pew Research Center, between 2000 and 2015 the percentage of Americans adults age 18 and over who did not use the Internet shrank from $48 \%$ to just $15 \%$. By 2015, the largest gaps in web usage were by age, not by race/ethnicity, education or urban/rural residence. Most nonusers are now elderly: $39 \%$ of Americans 65 and over were not on the Internet, whereas only $3 \%$ of those 18-29 said they did not use the web (Anderson and Perrin 2015).

Denizens of the virtual realm are not exclusively citizens of developed countries. Social media have been adopted in a big way across many parts of the world. Table 1 shows the 10 countries of the world with the largest number of Facebook users as reported by Statistica.com (2016). I calculated usage rates to net out the size differentials in the population pools of potential users. The percentages of the population 15 years of age and older who are Facebook users in Mexico and Brazil are almost as high as in the USA. Almost the same percentages of Indonesians and French are on Facebook, and Indonesians are more likely to be users than Italians.

Facebook is, of course, but one of many social media. It has been blocked since 2009 in China. To provide some comparative perspective for the world's most populous 
Table 1 Countries with the most Facebook users and penetration rates of Weibo and Twitter in China and the USA

\begin{tabular}{llcl}
\hline Country & $\begin{array}{l}\text { Facebook users } \\
\text { in 2014 (millions) }\end{array}$ & $\begin{array}{l}\text { Population age 15 } \\
\text { and over (millions) }\end{array}$ & $\begin{array}{l}\text { Users as a percent of } \\
\text { population 15 and over }\end{array}$ \\
\hline USA & 151.8 & 257.3 & 59 \\
India & 108.9 & 894.4 & 12 \\
Brazil & 70.5 & 154.1 & 46 \\
Indonesia & 60.3 & 178.6 & 34 \\
Mexico & 44.4 & 86.2 & 52 \\
UK & 30.3 & 52.9 & 57 \\
Japan & 26.5 & 105.9 & 25 \\
France & 22.4 & 52.6 & 43 \\
Germany & 22.0 & 70.4 & 31 \\
Italy & 18.3 & 52.7 & 35 \\
China-Weibo users 2015 & 222 & 1138.7 & 19 \\
USA-Twitter users 2015 & 51.5 & 257.3 & 20 \\
\hline
\end{tabular}

Sources: Statistica.com (2014), Population Reference Bureau (2014, 2015), China Internet Watch (2015) and Duggan (2015) and calculations by the author

country, I added a line to Table 1 showing usage of Weibo among the Chinese. Weibo is similar to Twitter, and the usage rates of these two social media programs are virtually identical in China and the USA.

Prevalence of media usage has not only a spatial dimension, but also a temporal one. Among its most enthusiastic adopters, American university students now spend inordinate amounts of time on their cell phones. A 2014 study conducted at Baylor University and reported in the Journal of Behavioral Addictions (whose contents include many studies of internet usage) found cell phone addiction to be rampant. Male college students reported spending almost $7 \mathrm{~h}$ and $30 \mathrm{~min}$ a day on their cell phones and females an average of $10 \mathrm{~h}$ ! Most of the gender difference was due to time spent on various social media, with one of the largest differentials being that for Pinterest: $26.1 \mathrm{~min}$ on average for females versus only $5.7 \mathrm{~min}$ for males (Petnji et al. 2014).

In the remainder of this address, I would like to first give a few observations about the impact of the web world on various aspects of daily lives. And then I'll offer a few thoughts about what distance - that lifelong object of fascination of mine-means in the context of the Internet. The web world is one where all basic regional science constructs of location and distance do not function the same as in, say, Weberian location theory.

\section{Boots on the ground; minds in the more/less world of the web}

We now live lives with our boots (mostly) on the ground, somewhere here on planet Earth, but with at least a portion of our minds off somewhere in the brave new world of the web. And in that world, there is precious little terra firma. Whereas the physical world has, over history, become a shrunken headspace, that of the web is a mindbogglingly expanding one. 
For any one of us, most of the web is like those spaces off on the edge of ancient parchment maps labeled Terra Incognito. How many countries of the web can one ever hope to explore in a lifetime of travel? And yet its child's play to abracadabra ourselves off to wherever in the vastness of the virtual world's terrain; it takes a mere few suggestive words keystroked or spoken into a search engine or mobile device. There's really only one constraining factor to going sightseeing in virtual space or to looking up whatever arcane fact or personal interest or opinion somebody else on the planet has chosen to share with the rest of us: time.

I have to think that one of the most radical changes to have come about during my career is how we allocate our minutes, hours, and days. We navigate along our life lines rather differently than the local people did for most of human history, or even how jet-setters did in the 1960s. We need more regional science research about the spatial implications of what goes on in the web world in addition to more psychological studies of the schizophrenia that more and more of the planet's inhabitants are exhibiting as they flit back and forth, trying to have it all, attempting to live simultaneously in both physical and virtual realms.

Has the web replaced the attenuating effect of distance with an attenuating effect on attention? While the great majority of all human know-how now lies at our fingertips, cell phone texting, internet-browsing and related addictions eat away the focused time people once spent sitting and reading, learning, and appreciating. Twittering your life away has become a literal danger.

Over the course of an academic career, a young scholar in our field will likely publish far more than even the most prolific of those in the early ranks of regional science researchers: the Walter Isards, Ed Ullmans, Bill Alonso's, Brian Berry's, Charlie Tiebouts, Charlie Levens of the days of yore. But having incentivized quantity, specialization and technical prowess, are we seeing less big-picture conceptualization? Are we in the Academy engaged in writing songs that, increasingly, voices never share? Who has time, anymore, to look up even a fraction of our current generation's output?

The same is true, of course, in virtually all fields of endeavor. Take the case of fiction writing. In an email exchange with a publisher the other day, I was told that Amazon now has up online four million eBooks.

Ever more and more: This is a guiding principle that has become engrained in how we think. There is always another indifference curve, up there to the northeast. Americans are uncommonly interested in forever wanting more and more, of seeking new frontiers, of wondering what lies over the next ridge. UCLA psychiatrist and neuroscientist, Peter Whybrow, wrote an interesting book titled: American mania: When more is not enough. He thinks there may be a genetic component to this particular type of obsessiveness: that migration to the USA selectively favored those with a predisposition to restlessness, to an urge to explore, to taking risks, and to his specialty disorder: manic depression (Whybrow 2005). But what happens when the American Dream comes true, what then? It's a question lurking not just for the wealthy in America, but one that takes on relevance for increasing proportions of the world's people, as better health, longer life spans, and greater material prosperity diffuses across the globe.

Within the next few generations, global population dynamics will stop being "ever more and more." But to deal with the rising affluence of the bulk of the expected 9 or 
10 billion earthlings, economies and societies critically need to figure out how to do more with less.

In another, more micro-sense, I think we need to foster a change in mindset: away from more/more to more/less. When parceling out our precious minutes of every waking day to physical and/or virtual activities, we ought to be subconsciously implementing Mies van der Rohe's concept of "less is more." I fear we really aren't yet very good modern architects at structuring our new combo interactions in body and mind space. It is all too easy to be dazzled by the thousand suns rising together into the sky (or should that be the cloud?) of cyberspace. I fear that we've been seduced by the endlessness of possibility and risk floundering about in a postmodernistic reality where doing more and more adds up to far less than that for which we now have the potential.

I worry, too, that despite the best of intentions and new archival methods, we aren't keeping track and making sense of the most salient of the goings-on in the information age. Over the summer, our University of Arizona School of Geography and Development moved to a new state-of-the-art environmentally green building. After working in the same office spaces for 35 years, I could no longer keep it all. So I trashed multiple dumpster loads of paper: hardcopies of journals I had subscribed to or edited; a fifteen-foot shelf full of other papers I had photocopied; box after box of offprints of articles I had authored; two ceiling-high file cabinets of class notes, syllabi, old examinations and memos I had squirreled away. It was, actually, sort of liberating, in a bittersweet way. So why, then, do I get abnormally sad about the prospect of jettisoning my CD music collection, my thousands of Kodachrome slides? We don't all merit the building of Presidential libraries, but still... As we madly plow our furrowed fields, hell-bent on putting ever more and more pixel dust up onto the cloud, we might want to wipe our brows and ask ourselves, where have all the flowers gone? Où sont les neiges d'antan?

The late economist/poet Ken Boulding once observed:

It is a very fundamental principle indeed that knowledge is always gained by the orderly loss of information; that is, by condensing and abstracting, and indexing the great confusing buzzing of information that comes from the world around us into a form we can appreciate and comprehend. (Boulding 1958, p. 2)

We've become adept at exponentially increasing the speed and storage capacities of computers, at proliferating and adopting the latest mobile technologies, at enthusiastically embracing the newest and sexiest social media. But how successful have we been in advancing methods for the orderly losing of information that leads to gains in knowledge? Is this, perhaps, somewhere where folks with expertise in locational analysis could lend a helping hand?

\section{Where in the web are we?}

The time-geography concept of coupling constraints imposes rather binding choice sets on which activities one can physically partake in. Venn-diagramming others' activity spaces can show us the sets of people we might possibly see, and interact 
with, in the flesh. During the auto age, metropolitan areas have become our functional settlement geography. A metro area is a portion of the planet where a large number of individuals' daily activities overlap, where activity spaces stack up in big piles. Which leads me to ask: what are the metro areas of the Internet?

To explore that question, let us think about some of the primitives of the virtual geography of what I have been calling the web world. In terms of the concept of absolute location, it is an ensemble of dispersed users accessing Web sites or, through various media, connecting with other users. The physical locations of the users and the servers hosting the Web sites are practically irrelevant. Web sites contain, however, links to other sites; users may click on multiple sites brought up on a single search; and users communicate either pairwise or in groups-in chat rooms, listservers, and the like. So we have the makings for a concept of relative location as well.

Clustering together the calls, Web site hits, people hanging out in the same chat room, those checking up on each other's Facebook pages and so forth, we could conceive of a counterpart to time-geographic activity spaces. Individuals spend time accessing bundles of virtual locations and communicating along with others of similar mind bents lurking in the same virtual vicinity. On the Internet, proximity is not defined by nearness in physical space but rather by proximity in a kind of affinity space. Subsets of users with similar interests more heavily access certain Web sites in the domain of those interests and may connect up with other users sharing such interests. Web metropolises, therefore, are where there are heavy stacks of users pursuing linked activities and where user communities link up to communicate about mutual concerns. Unlike the audiences for the mass media of the 1970s, e.g., metropolitan area newspapers and local broadcast television stations, the clusters of users sharing affinity spaces in the web world of the Internet are not necessarily bounded by any sort of physical distance-decay considerations.

Increasingly, people can choose to spend their time interacting in the web world with those inhabiting similar affinity spaces and thereby feel less compunction, as in the past, to socialize with those in physical proximity. Living in a gated community where you push the garage door opener, drive into your garage and never meet your neighbors does not consign you to the lonely life of a hermit.

At the same time, many trends suggest that physical proximity is actually becoming more, not less, prized. Humans are gregarious animals. Emerging adults and emptynesters are flocking back to live in old American downtowns, attending more live events, going out to restaurants, drinking in bars, eating local foods. Because fewer physical trips are needed to take care of basic needs, engaging in activities in the flesh may be becoming more highly prized for discretionary activities. No longer does one have to go get cash from a human teller at a bank window during week-day banker hours. No longer does one have to go to the shelves at bookstore or the stacks of a library to peruse books one might want to read. For the activities that we still do in person, physical proximity matters more, rather than less, because we have now become only part-time residents of the material world.

What have long been considered modes of "communications" are gaining new materialities of function. Leamer and Storper (2001) contended that the Internet allows for communications, but not for handshaking. Yet, more and more activities that 
required physical action, and thus physical presence, are becoming possible to carry out remotely. We are all becoming, in a sense, drone operators. Using the app on my cell phone, while at a WRSA Annual Meeting in Hawaii I can turn off the burglar alarm at our house back in Tucson in order to allow access by our housecleaner. Lying on a Hawaiian beach, I could even view and dispatch photos of a home burglar to our county sheriff's office. Were we to invest in nascent smart appliance and smart home technology, I would also be able to remotely roast a pot roast—or maybe even water my wife's houseplant jungle.

\section{A few closing words: on "and/or-ness" and about regions of time}

Since I have not wholly succeeded in my vow of brevity, I would like to wrap up by calling attention to two more things. The first concerns one final, small aspect of my address's title: Regional science in a physical/virtual more/less world. That aspect is this: /, the forward slash that I used to separate physical from virtual and more from less.

In 1984, at the Denver North American Meetings of the Regional Science Association, Walter Isard asked me to become an editor of the Papers. Among other things, that assignment motivated me to study grammatical rules and punctuation. I learned that, typographically speaking, a forward slash is called a solidus. It is named after a gold coin of the late Roman Empire. Originally, the mark was not a straight slanting line, /, but rather the formerly deployed English long S: $\int$. It came into usage to separate shillings from pence, as in ${ }^{7} \int_{6}$, "7 shillings 6 pence." It is used now to separate any pair of alternatives, most notably, perhaps, and/or. Sometimes, in fact, we read a solidus aloud as "and/or": Regional science in a physical and/or virtual more and/or less world.

The solidus has also come to connote vagueness or lack of specificity: what I like to think of as and/or-ness. For the reasons I've detailed in the earlier sections of this address, going forward people will increasingly lead lives in a world replete with uncertainties, where many of the critical questions will involve the and/or-ness of physical/virtual and more/less. Regional science, I suspect, will remain highly relevant. The subject matter of our multidisciplinary field, however, will become ever more challenging as awareness spaces continue to grow and evolve, and as the locations of feasible activities further transcend the geometries of earthbound space.

A paper titled "Regions of Time," which was given at that 1984 North American Meetings in Denver, is still among the most memorable of all the many articles that I chose to publish during my two-decade career as a journal editor. Kenneth Boulding asserted that:

All regions are patterns in time as well as in space. They can be thought of, indeed, as patterns in space-time. The same can be said of their boundaries... It is not always easy to identify a region or a boundary, for these discontinuities are not unrelated to the limitations and capabilities of human perception. (Boulding 1985 , p. 20)

I believe the development of the worldwide web, with new functionalities of information access and telecommunications, marks a significant watershed in human history. 
We have now entered a region of time where individuals' daily activity patterns are no longer limited to traditional time-space prisms. Advanced forms of regional science will be needed to help understand new locational forces and to help meet new societal needs in a world where people's lives increasingly interpenetrate in cyberspace.

People may well continue to prefer shorter trips to longer trips, but the trips they take may either be journeys spanning physical distance or pixeling off into affinity space. And, at some scale, people may still prefer more to less space. Or maybe not. As the world has globalized, more and more inhabitants have flocked to high-density megacities. The web has made it infinitely easier to access vast swatches of topical knowledge. I would hope that people will want to inhabit ever broader tracts of affinity space, while living closer together in physical space.

As individuals have become better and better connected, institutions and societal norms have faced stresses. Nation-states have experimented with combining into new transnational units, while some of the same forces have led to a reasserted importance for regions and localities. At multiple scales, there is still more and more to be learned in regional science.

At this juncture of history, as the demographic transition is brought to a close, we need to deal with the repercussions and consequences of an extraordinary period of explosive global population growth. We desperately have to figure out how to make more from less, as well as figuring out how to share the bounty of the earth with many more of the world's peoples. On a scarily pressing basis, we must come to grips with how to live together within the friendly confines of our material planet, and with how to strictly respect its natural resource endowments and environmental systems.

Our age is the one when humans became no longer tyrannized by distance. We have gained the ability to take our individual life paths pretty much wherever we desire. No longer multiplying in ever-increasing numbers, we can now go forth and explore the totality of human experience in the uncharted communities of an ever-expanding, interconnected, intergalactic web. A whole lot more meaningfulness becomes attainable in the growing awareness space of an evolving physical/ethereal, more/less world. Conquering the forces of attenuation and rising together, we hold the power to grasp the glory of the shape of the infinite.

Acknowledgments The author thanks Editor-in-Chief Janet Kohlhase as well as a number of others in attendance at the banquet luncheon on February 16, 2016 at the WRSA's 55th Annual Meeting. Their insightful reactions and excellent suggestions resulted in a number of revisions and improvements to the original text of this presidential address.

\section{References}

Anderson M, Perrin A (2015) Fact tank, July 28, 2015: $15 \%$ of Americans don't use the internet. Who are they? Pew Research Center, Washington. www.pewresearch.org/fact-tank/2015/07/28/ 15-of-americans-dont-use-the-internet-who-are-they. Last Accessed 13 July 2016

Boulding KE (1958) The skills of the economist. Howard Allen Inc., New York

Boulding KE (1985) Regions of time. Pap Reg Sci Assoc 57:19-32

Brown LA, Moore EG (1970) The intra-urban migration process: a perspective. Geogr Ann 52B:1-13

China Internet Watch (2015) www.chinainternetwatch.com/16366/weibo-search-users-insights-2015. Last Accessed 28 June 2016 
Duggan M (2015) The demographics of social media users. Pew Research Center, Washington. www. pewinternet.org/2015/08/19/the-demographics-of-social-media-users. Last Accessed 13 July 2016

Franklin RS, Plane DA (2016) The view from over the hill: regional research in a post-demographic transition world. In: Jackson R, Schaeffer P (eds) Regional research frontiers: the next 50 years. Springer, Berlin (forthcoming)

Hägerstrand T (1970) What about people in regional science? Pap Reg Sci Assoc 24:7-21

Horton FE, Reynolds DR (1971) Effects of urban spatial structure on individual behavior. Econ Geogr 47:36-48

Janelle DG (1968) Central place development in a time-space framework. Prof Geogr 20:5-10

Leiner BM, Cerf GC, Clark DD, Kahn RE, Kleinrock L, Lynch DC, Postel J, Roberts LG, Wolff S (2016) A brief history of the internet. http://www.internetsociety.org/internet/what-internet/history-internet/ brief-history-internet. Last Accessed 2 Feb 2016

Leamer EE, Storper M (2001) The economic geography of the internet age. National Bureau of Economic Research working paper series, vol 8450. NBER, Cambridge

Lewin K (1951) Field theory in social science. Harper and Row, New York

Meinig DW (2004) The shaping of America: a geographical perspective on 500 years of history, volume 4: global America, 1915-2000. Yale University Press, New Haven

Population Reference Bureau (2014) 2014 World population data sheet. www.prb.org/publications/ datasheets/2014/2014-world-population-data-sheet.aspx. Last Accessed 12 July 2016

Population Reference Bureau (2015) 2015 World population data sheet. www.prb.org/Publications/ Datasheets/2015/2015-world-population-data-sheet.aspx. Last Accessed 12 July 2016

Pred AR (1973) Urban growth and the circulation of information: the United States system of cities, 17901840. Harvard University Press, Cambridge

Roberts JA, Petnji Yaya LH, Manolis C (2014) The invisible addiction: cell-phone activities and addiction among male and female college students. J Behav Addict 3:254-265

Statistica.com (2014) Leading countries based on number of Facebook users as of May 2014 (in millions). www.statistica.com/statistics/268136/top-15-countries-based-on-number-of-facebook-users/. Last Accessed 28 June 2016

U.S. Bureau of Labor Statistics (2016) American Time Use Survey-2015 results. www.bls.gov/news. release/atus.nr0.htm. Last Accessed 12 July 2016

Warf B (2013) Global geographies of the internet. Springer, Dordrecht

Wolpert J (1965) Behavioral aspects of the decision to migrate. Pap Reg Sci Assoc 15:159-169

Whybrow PE (2005) American mania: when more is not enough. WW Norton, New York 